This item was submitted to Loughborough's Research Repository by the author.

Items in Figshare are protected by copyright, with all rights reserved, unless otherwise indicated.

\title{
The survival potential of companies placed into administrative receivership
}

PLEASE CITE THE PUBLISHED VERSION

PUBLISHER

(C) Emerald

LICENCE

CC BY-NC-ND 4.0

\section{REPOSITORY RECORD}

Hamilton, Robert, Barry Howcroft, Zhonghua Liu, and Keith Pond. 2019. "The Survival Potential of Companies Placed into Administrative Receivership”. figshare. https://hdl.handle.net/2134/1215. 
This item was submitted to Loughborough's Institutional Repository by the author and is made available under the following Creative Commons Licence conditions.

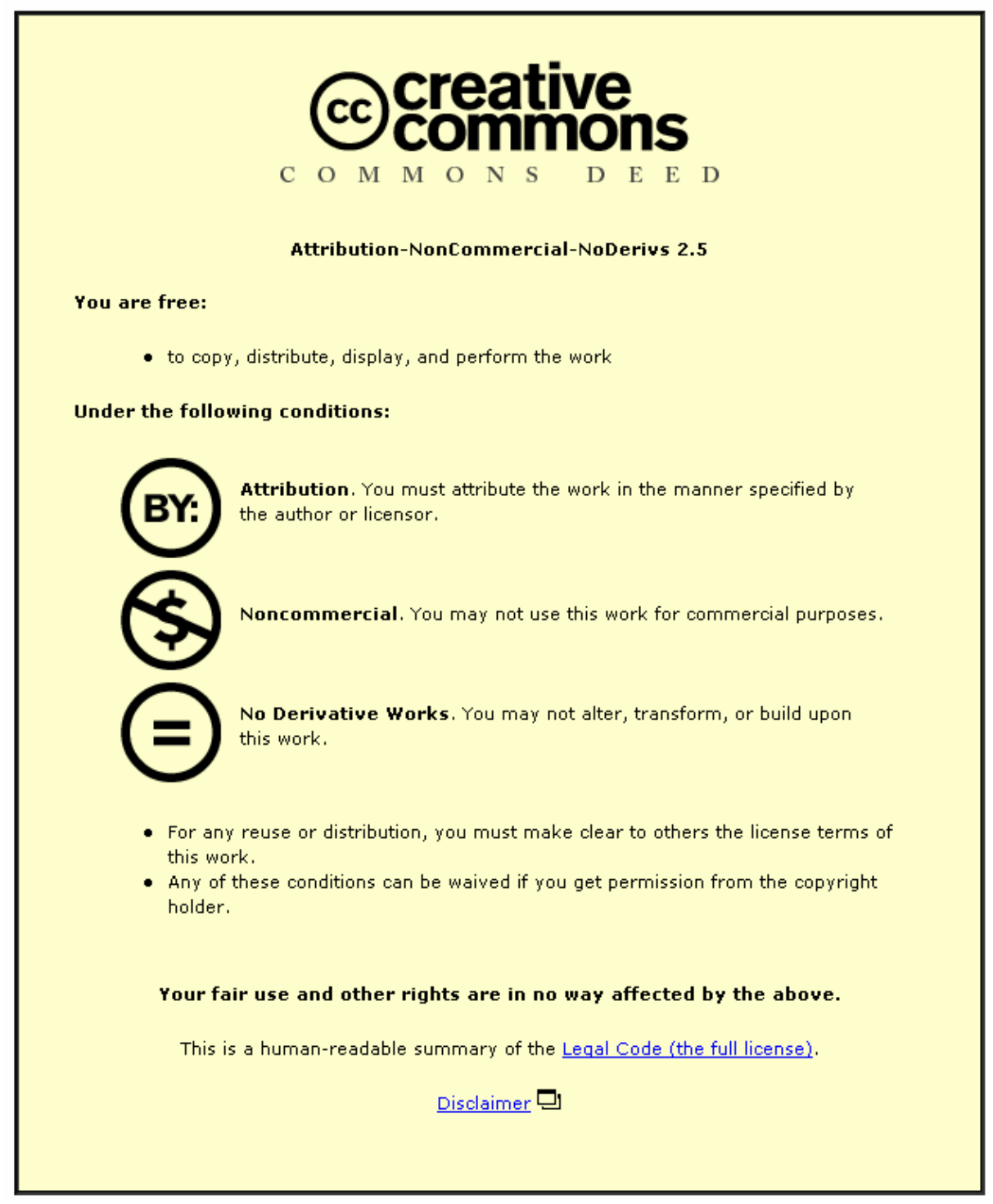

For the full text of this licence, please go to: http://creativecommons.org/licenses/by-nc-nd/2.5/ 


\title{
Loughborough University
}

\section{The Survival Potential of Companies Placed into Administrative Receivership}

\author{
by
}

Robert Hamilton ${ }^{1}$, Barry Howcroft ${ }^{2}$, Zhonghua Liu $^{3}$ and Keith Pond ${ }^{4}$

October 2001

\footnotetext{
1 Lecturer, Business School, Loughborough University.

2 Professor of Retail Banking and Director of Loughborough University Banking Centre.

3 Visiting Research Fellow, Loughborough University Banking Centre.

4 Lecturer, Business School, Loughborough University.
} 


\begin{abstract}
The paper focuses on a sample of companies, which have been placed into administrative receivership, and attempts to assess whether financial ratios used by lending banks can be identified and used to discriminate between companies which can be rescued and those which will fail. The distinctiveness of the paper lies in the fact that it applies conventional bank lending ratios, rather than prediction of failure ratios, to a sample of companies and is primarily concerned with the prediction of corporate survival rather than the prediction of corporate failure. The research compares two statistical classification techniques - Linear Discriminant Analysis and Logistic Regression - to ascertain which is the best at predicting eventual outcomes. A number of further issues, relating to which financial ratios are the most important in predicting future outcomes and the additional insight these financial ratios provide in helping to explain why companies move into crisis and why some companies are rescued and others fail, are also discussed in the paper.
\end{abstract}


KEYWORDS

Company Rescues

Administrative Receiverships

Prediction

Bank Lending Ratios 


\section{INTRODUCTION}

Under UK legislation (Insolvency Act 1986) with its current emphasis on promoting a rescue culture, insolvent companies can either be liquidated or rescued as going concerns. In the latter instance, companies can be placed either into administrative receivership or reorganised under a Corporate Voluntary Arrangement, with or without the protection of an Administration Order. Against this legal framework, the research seeks to establish whether financial ratios normally used by lending banks to ascertain credit worthiness can be used to discriminate between companies which can be rescued and those which cannot. This is an important question because administrative receivers are almost exclusively appointed by lending banks and they are also typically asked to give their approval to rescue schemes under voluntary arrangements. If conventional bank lending ratios could be used in this way, it suggests that a significant amount of time, effort and expense could be saved. Companies, for example, which might have otherwise been the subject of unsuccessful rescue attempts could be more readily identified and placed into immediate liquidation. Conversely, companies which might have been placed directly into liquidation could be similarly identified as having a good chance of survival under a rescue package.

Whilst recognising the important academic contribution of Beaver (1966), Altman (1968), Argenti (1976) and Taffler and Tisshaw (1977) in the prediction of corporate failure, Gilbert et al (1990) have argued that ex poste discrimination between risky companies which have failed and non-risky companies which have not has limited practical value. As a consequence, Gilbert et al's study focussed on whether financial ratios can be used to distinguish between weak companies that are destined to go into liquidation and weak companies that will avoid liquidation. The overall accuracy of their model was 78.3 per cent with 90.6 per cent of weak firms that avoided insolvency being correctly predicted. Perhaps more significant, however, was the fact that only 29.2 per cent of weak firms which eventually went into liquidation were correctly predicted.

In developing this approach further, the paper reduces any ambiguity which could be associated with the term "weak companies" by focussing on a sample of companies which were placed into administrative receivership by their lending banks. As such, the companies which comprise the sample have all experienced some form of crisis or "weakness” and are, 
therefore, broadly comparable. The real distinctiveness of the paper, however, lies in the fact that it applies conventional bank lending ratios to the sample in an attempt to predict whether the companies have a chance of being rescued. In contrast to previous studies, therefore, the emphasis is on survival rather than failure and the ratios used in the analysis are typically associated with credit assessment rather than the prediction of failure. The paper also uses the Statistical Package for Social Sciences (SPSS) to compare and contrast two statistical classification techniques, namely, Linear Discriminant Analysis (LDA) and Logistic Regression (LR), in modeling the likely outcomes for the sample companies and in determining which of the financial ratios used in the analysis have the most predictive power.

\section{RESEARCH QUESTIONS}

Having regard for the above discussion, the research identified and focussed upon the following hypothesis:

$\mathrm{H}_{\mathrm{O}}=$ it is possible to successfully predict the chances of recovery for a company placed into administrative receivership by using financial ratios used by lending banks.

A further three research questions emanated from this overall hypothesis:

- $\quad \mathrm{R}_{1}$ : Which of the two classification techniques is the best at predicting eventual outcomes?

- $\quad \mathrm{R}_{2}$ : What are the most important financial ratios in predicting the future likely outcomes of companies placed into administrative receivership?

- $\mathrm{R}_{3}$ : What insights do these financial ratios provide in helping to explain why companies become weak and why some are rescued and others liquidated? 


\section{CLASSIFICATION PROCEDURES}

\section{Linear Discriminant Analysis}

Discriminant analysis refers to several closely related activities used for deriving and interpreting a discriminant model which categorises individual cases into several prespecified classes (Klecka, 1980). The most widely used discriminant model is the linear model (see, for example, Crook et al, 1992) which consists of one or more discriminant functions in the following form:

$$
\begin{aligned}
& f(x)=b_{0}+b_{1} x_{1}+b_{2} x_{2}+\ldots+b_{n} x_{n} \\
& \text { where: } \quad x=\left(x_{1}, x_{2}, \ldots, x_{n}\right), \\
& \\
& x_{i} \text { 's are explanatory variables, } \\
& b_{i} \text { 's are the estimated coefficients. }
\end{aligned}
$$

Under certain assumptions, such as multivariate normality and equal covariance matrices, the coefficients can be derived using the Fisher procedure by maximizing the ratio of between groups variances to within groups variances. The value of a discriminant function is called the discriminant score, which can be used directly for classification purposes ${ }^{1}$.

\section{Logistic Regression}

The logistic regression model is a probability model, which can directly estimate the probability of an event occurring (or not occurring), and can therefore be used in the binary classification problem (Draper and Smith, 1981; Breiman et al, 1993). The logistic regression model, for more than one independent variable, can be written as:

$$
\begin{aligned}
& \text { Prob (event) }=\frac{1}{1+\mathrm{e}^{-\mathrm{z}}} \\
& \begin{aligned}
\text { where: } \mathrm{z}=\mathrm{b}_{0}+\mathrm{b}_{1} \mathrm{x}_{1}+\mathrm{b}_{2} \mathrm{x}_{2}+\ldots+\mathrm{b}_{\mathrm{n}} \mathrm{x}_{\mathrm{n}}, \\
\mathrm{b} \text { 's }=\text { estimated coefficients, }
\end{aligned}
\end{aligned}
$$


$\mathrm{e}=$ the base of the natural logorithms,

and Prob (no event) = 1 - Prob (event).

The logistic regression model is a generalized linear model as the variables are used in the form of linear combinations. The parameters are estimated using the maximum-likelihood method through an iterative non-linear regression procedure. In practice, it has been suggested that the logistic regression approach is often preferred over discriminant analysis (Press and Wilson, 1978), although arguably the interpretation of the coefficients in a LR model are less obvious than in a LDA model.

\section{SAMPLE DATA}

The DTI Statistics Directorate revealed that in 1998 1,713 companies were placed into administrative receivership and financial information relating to some of these companies for the previous two years was available on the FAME (Financial Analysis Made Easy) CD Rom database. As the financial data on FAME is based on historical audited accounts, there was, however, a time discrepancy between the two sources of data. Specifically, the financial data on FAME related to the period September 1996 to March 1998, ie approximately one to two years before some of the companies were placed into receivership. Although it was recognised that this consideration could influence the classification results, it was not regarded as a major problem because lending bankers predominantly base their credit decisions on historical data contained in the latest audited accounts. It was concluded, therefore, that the time discrepancy between the two sources of data broadly reflects the "real world” situation.

The FAME database was, however, incomplete in two important respects: firstly, subsidiary companies placed into receivership are reported as separate companies in the statistics, whereas the data in FAME is based on consolidated accounts. Consequently, a high incidence of group companies placed into receivership increases the disparity between the two sources of data. Secondly, the FAME database relates almost entirely to medium-large sized companies. The authors estimate that at least 90 per cent of the companies on FAME had annual sales turnovers exceeding $£ 500,000$, a figure which approximated with the largest 
10 per cent of companies registered in the UK in 1998. These considerations reduced the sample to 120 medium-large sized companies.

The London Gazette was used to identify the administrative receivers (ie the individual insolvency practitioners) responsible for each of these 120 companies. However, the Gazette did not reveal the eventual outcomes of the receiverships. Questionnaires were, therefore, forwarded to each of the named receivers requesting information about the eventual outcomes of the receiverships. The remittance of the questionnaire resulted in 74 usable responses (see Table 1) and these revealed that 49 companies were sold on a complete or partial basis (designated “rescued” cases ) and 25 companies went into liquidation (designated “failed" cases).

\section{INSERT TABLE 1}

In terms of identifying and determining the appropriateness of the variables for inclusion in the analysis, twenty operating and financial ratios were considered, as shown in Table 2. As discussed in Bathory (1987), these ratios are associated with credit assessment rather than the prediction of failure and are typical of the ratios used by lending bankers in granting and controlling credit facilities and in determining the appropriateness of an administrative receivership.

Six ratios were eventually used in the analysis. These included four operating ratios - gross profit (PM), ie profit before interest and tax/sales turnover; stock turnover (ST); debtor turnover (DT); and two financial ratios: gearing ratios (GR), ie debt/equity, and the current ratio (CR), ie current assets/current liabilities. The ratios not used in the analysis were excluded for a number of reasons. It was difficult, for example, to calculate meaningful figures for capital employed because many of the companies had experienced substantial negative profits. In addition, the FAME database did not contain consistent information on trade creditors, trading profits and interest paid. Consequently, a number of ratios were excluded on the basis of missing values. However, as most of these were correlated with the six ratios used in the analysis, this was not regarded as too serious a problem. Possibly the only exception, in this respect, was interest gearing, ie PBIT/interest paid, which is not 
correlated to any of the six ratios used in the analysis, but was omitted on the grounds of missing values.

Although using conventional bank lending ratios is a move towards replicating the sort of criteria applied by banks when appointing administrative receivers, it was recognised that this approach could introduce a number of problems. For example, whereas healthy companies usually have financial ratios which are broadly comparable, companies are placed into administrative receivership for a variety of different reasons and this typically reveals itself in a much wider spread of values for the financial ratios. This suggested that the predictive structure of the data for insolvent companies might be less accurate than that for solvent companies.

\section{INSERT TABLE 2}

Another problem stemmed from the fact that as the "actual" population of rescued and failed companies placed into administrative receivership during 1998 was not available, it was difficult to know what proportions of rescued and failed companies to include in the data set. Although this is not an issue when deriving functions (1) and (2), it is, however, a problem when it comes to assessing the performance of the functions. In the case of discriminant analysis when the two groups are unequal, the prior probabilities influence the classification procedure (and favour the largest group), whereas if the groups are equal, each group’s prior probabilities are equal. $^{2}$ Similarly with logistic regression, where you have two unequal groups, most cases will be assigned to the larger group regardless. Consequently, it was decided to conduct the analysis by using two data sets from the sample:

(i) data set RE74 (unequal groups) consisted of all 74 companies (49 rescued and 25 failed); and

(ii) data set RE50 (equal groups) consisted of 50 companies. This data set included the 25 failed companies and a further 25 companies were randomly selected from 49 rescued companies. 
Given the assumptions of the multivariate statistical techniques being used in this work, all the independent variables were tested for multicollinearity ${ }^{3}$ and only variables with a tolerance (see Crook et al, 1992) greater than 0.9 remained in any model.

Given the nature of the data (ie all variables were continuous) and the relatively small sample size (ie $n=74$ ), the values for each independent variable were split into categories or classes and the value for each class was calculated as the odds to be rescued (see Lewis, 1994).

Odds to be rescued $=\mathrm{Nr} / \mathrm{Tr}$ $\mathrm{Nf} / \mathrm{Tf}$

where: $\mathrm{Nr}=$ number of rescued cases with values falling in the class,

$\operatorname{Tr}=$ total number of rescued cases,

$\mathrm{Nf}=$ number of failed cases with values falling in the class,

$\mathrm{Tf}=$ total number of failed cases.

Therefore, the values of a variable were divided into a number of value classes, such that the spread of values within a class was minimised and the difference between classes was maximised. For continuous variables, where the effect is not linear, this approach (see Hamilton and Khan, 1997) will provide more meaningful results and improve the predictive ability of the model.

\section{COMPARISON OF THE TWO CLASSIFICATION TECHNIQUES}

Table 3 and Table 4 show the LDA and LR classification results for datasets RE74 and RE50 respectively. The "apparent rate" in these tables is the classification rate when using the same dataset for analysis and classification. The estimated (or unbiased) classification rates were obtained through two validation methods (Eisenbeis, 1977): Jackknife and V-fold crossvalidation (7-fold for RE74 and 5-fold for RE50). The explanatory variables are also ranked according to their relative importance, as estimated by the standardized canonical coefficients in the case of LDA and by the R-statistic (partial correlation) in the case of LR. 
The results show that the performances of the two classification procedures are quite comparable, especially when all of the 6 explanatory variables are used. The estimated classification rates are between 70 and 80 percent. This is much higher than $C_{p}{ }^{4}$, the expected classification rate determined by chance (Hair et al, 1987 and Crook et al, 1992).

$$
\begin{aligned}
& \mathrm{C}_{\text {prop }}\left(\text { for dataset RE74) }=(49 / 74)^{2}+(25 / 74)^{2}=55.25 \%\right. \\
& \text { and } \\
& C_{\text {prop }}\left(\text { for dataset RE50) }=(25 / 50)^{2}+(25 / 50)^{2}=50.0 \%\right. \text {. }
\end{aligned}
$$

The performance of the classification techniques on the equal-groups dataset RE50 was better than on the unequal-groups dataset RE74, in terms of both the apparent rate and the estimated rate. Finally, the overall predictive accuracy of the models was between 85 - 90 percent for the "rescued" group, and between 55 - 60 percent for the "failed" group.

\section{INTERPRETATION OF THE KEY RATIOS}

\section{Debtor Turnover}

The analysis revealed that when debtor turnover (DT) fell between 64 days (which was the average collection period in the sample) and 140 days, companies had a very good chance of being rescued: 27 out of 32 or just over 80 per cent of companies within this range were rescued. When DT was less than 64 days, however, the chance of a company being rescued was much lower at 52.4 per cent. This result was totally unexpected because a low debtor turnover figure is usually associated with efficient credit control and good management practice. It is perhaps pertinent to emphasise, however, that the companies under examination had all been placed into administrative receivership and were, therefore, by definition either weak or experiencing problems. In this respect perhaps these companies should not be regarded as typical or normal. This finding, however, does raise an important 
question about whether these companies are placing too much emphasis on credit control at the expense of marketing and sales promotion?

In attempting to resolve this question, the analysis focussed on the 42 sample companies with a debtor turnover of less than 64 days and examined their turnover trends (TT). This was calculated as the percentage change in turnover, ie an increase or decrease, over the two years set of accounts.

\section{INSERT TABLE 5}

As Table 5 shows, although these companies are comparable in terms of DT, they are far from homogenous in terms of TT or the eventual outcome of the receivership. The largest group was the 26 companies which exhibited a declining TT and out of these 12 failed. This observation seems to underline just how important a declining sales turnover is in indicating whether a company will move into difficulties and eventually fail. The high failure rate in this category could be indicative of secular decline, ineffective marketing, obsolete products or price uncompetitiveness, etc, and reflects the attempts of management to survive by exclusively pursuing a rigorous credit control policy. Regarding the 14 companies which were rescued, a similar policy of focussing on credit control is exhibited, but as these companies survived, there was presumably a viable business and a market which the original management failed to exploit.

The 9 companies with TT between 0-15 per cent are simultaneously pursuing credit control and sales promotion policies. Having regard for the UK rate of inflation in 1998 which was between 2-3 per cent, a sales turnover much beyond 4 per cent would have been acceptable, but sales growth in excess of this may have been indicative of overtrading. These considerations, aligned with low debtor figures and taking into account the fact that the majority of these businesses were rescued, suggests that they were viable concerns but needed additional external finance to consolidate their positions. The remaining 7 companies which exhibited TT greater than 15 per cent are similar to the middle range companies inasmuch as they are probably overtrading but to a much greater extent, and this probably explains why only one of them was rescued. High sales turnover may also have been facilitated by substantial discounts and commensurately lower levels of profitability. Under 
these circumstances working capital would deteriorate and further explain the relatively high number of failed cases.

\section{Gearing Ratio}

The findings are also interesting with regard to the gearing ratio (Table 6). It is generally accepted that lending banks do not normally lend more than the "net worth" of the company, with net worth typically including equity plus retained profits and capital revaluations less intangible assets such as goodwill, patents, etc. The gearing ratio used in the analysis, however, was debt/equity and it was, therefore, anticipated that the ratio used in the analysis would tend to exaggerate or increase the level of gearing compared with the method of calculation normally used by banks. On this basis, a gearing ratio falling below 2.0 was interpreted as being low; a gearing ratio falling within the range 2.0-10.0 was interpreted as being fairly normal; and anything in excess of this range was regarded as being high to excessive.

\section{INSERT TABLE 6}

Table 6 shows that companies with low gearing ratios, ie below 2.0, have a good chance of being rescued, as only 2 of the 12 cases in this category failed. This suggests that these companies might have pursued too conservative a financial policy and, therefore, might have failed to fully exploit their sales potential and maximise their profitability. The fact that most of these companies were rescued certainly suggested that they operated in viable markets, but perhaps needed additional external finance to consolidate and improve their performances.

In contrast, companies in the gearing range 2.0-10.0, ie those which are fairly "normal”, have a much greater chance of not being rescued as 11 of the 17 failed. This suggests that the problem for these companies is not so much a weak or conservative financial policy, but something rather more substantive, possibly relating to the external market. It could, for example, be indicative of an obsolete product or a lack of price competitiveness due to diseconomies of scale or poor factory layout, etc. Companies in the two remaining ranges 10.0-70.0 and $>70.0$ accounted for 61 per cent of the sample and this suggests that the majority of companies in the sample might have got into difficulty because of excessive bank 
borrowing. Rather interesting is the fact that these companies have a good chance of being rescued (15 out of 23 companies in the 10.0-70.0 range and 18 out of 22 companies in the $>70.0$ range) and this may once again be indicative of simply borrowing too much and having inadequate financial control. The high incidence of rescued companies, however suggests that they are basically viable businesses operating in equally viable markets.

\section{Current Ratio}

The observed pattern with regard to the current ratio is shown in Table 7. Before examining the results, however, it is perhaps appropriate to establish that there is no "ideal" or "norm" for the current ratio. As with financial ratios generally, it is influenced by the industrial sector in which a company operates (Elliot and Elliot, 1993). It is generally accepted, however, that banks will not lend unsecured on a current ratio of less than unity and a ratio of 2:1 is generally regarding as providing additional comfort (Clemens and Dyer, 1979). Table 7 reveals that the majority of sample companies had current ratios of less than 1.10 , ie just slightly greater than unity. This was not unexpected as all of the companies were weak and had been placed into administrative receivership by commercial banks who are the principal external source of working capital to UK companies. Low current ratios, combined with full security in the form of a mortgage debenture ${ }^{5}$, might also be reflecting the UK lending banks' obsession with volumetric targeting. As a consequence, marginal cases might have been sanctioned or allowed to continue trading on the basis that the banks were fully secured.

\section{INSERT TABLE 7}

The results, rather interestingly, did not reveal any significant difference between the current ratios of rescued and failed companies. This would seem to suggest that although the current ratio might be useful as an early warning signal, it is essentially concerned with short-term liquidity rather than with insolvency and the long term survival of a company. In fact, the results in Table 7 reveal a profile which is not dissimilar to that for gearing (shown in Table 6). Companies, whose financial ratios fall into the two extreme ranges, have a good chance of being rescued, whereas companies in the middle ranges have a significantly less chance of being rescued. 
In contrast to low gearing, however, a low current ratio is not normally associated with a conservative financial policy. Rather it is connected with a substantial bank overdraft or a large outstanding taxation or trade creditor liability and may, therefore, be indicative of companies which are failing to generate sufficient cash flow to meet their immediate cash requirements. Similarly, a high current ratio in contrast to high gearing is not normally associated with excessive borrowing, but rather is normally associated with high levels of debtors or work in progress, etc. A build up of working capital, especially when a company is supposedly weak, may be indicative of poor internal management and relate to inadequate credit control, or an inappropriate pricing policy, etc, or reflect a lack of external competitiveness due to poor location or cyclical factors in the economy, etc. As the majority of companies which fell into the two extreme ranges were rescued, there is a tendency to conclude that their problems were essentially concerned with inadequate internal management rather than with external market conditions.

Companies which fell into the middle range for current ratios, ie 0.85 - 1.10, had only slightly more than a 50 per cent chance of being rescued. This suggests that these companies may have substantial overdrafts which have been invested in illiquid current assets, typically stock, work in progress, debtors, etc. Under these circumstances the current ratio will approximate to unity in that it will be "matched”, ie current liabilities will broadly equal current assets. As with the middle ranges for gearing, this indicates that although these companies’ problems might have been exacerbated by poor internal management, the fact that a high proportion failed is probably more indicative of adverse market conditions.

\section{CONCLUSION}

The research has examined the concept of prediction of "survivability" in corporate insolvency. As the sample size was small, it is perhaps unwise to claim that the model is unbiased in estimating the survival potential of companies placed in receivership. For similar reasons we would not even claim that the financial ratios identified in this study are necessarily the most useful in predicting rescue potential. However, the research has shown

some promising results on what is a difficult but potentially influential area of insolvency and commercial bank lending practice. 
With respect to the research hypothesis $\left(\mathrm{H}_{0}\right)$, the research revealed classification rates between 70 and 80 per cent which is much higher than Cprop, the expected classification rate determined by chance. The overall predictive accuracy of the models was between 85-90 per cent for the rescued companies and between 55-60 per cent for the failed group. The paper also provided some interesting insights into the related research questions. The performance of the two classification procedures $\left(\mathrm{R}_{1}\right)$ were comparable, especially when all six financial ratios were used in the analysis. In addressing the second research question $\left(\mathrm{R}_{2}\right)$, the paper identified three ratios, namely the current ratio, debtor turnover and the gearing ratio, as being particularly discriminative. As regards the final research question $\left(\mathrm{R}_{3}\right)$, the ratios appeared to have explainable patterns and, therefore, provided tentative insights into why some companies were rescued and others failed. Companies which were rescued typically exhibited either high or low current ratios, high or low gearing ratios and debtor turnover periods greater than sixty four days. Moreover, when this ratio profile occurred with a positive sales turnover, the chances of being rescued increased. In contrast, companies which failed typically had current and gearing ratios in the middle ranges, ie levels which are generally acceptable to lending banks. Equally interesting was the increased likelihood of failure for companies with debtor turnover periods of less than sixty four days, especially when this coincided with constant or declining sales turnover.

Finally, it must be emphasised that estimating the survival potential of companies is not the same as predicting the fates (outcomes) of companies under receivership, not least because the former are independent of the administrative receivers' influence. Another difference is that there is no standard for measuring the survival potential of "normal" companies, but the fate of companies placed into administrative receivership is known and is, therefore, measurable. The ability to predict the fate of companies placed into administrative receivership is, therefore, both practical and useful. 


\section{REFERENCES}

Altman, E I, (1968), Financial Ratios, Discriminant Analysis and the Prediction of Corporate Bankruptcy, Journal of Finance, Vol 23, pp 589-609.

Argenti, (1976), Corporate Collapse: The Causes and Symptoms, McGraw-Hill.

Bathory, A, (1987), The Analysis of Credit, Foundations and Development of Corporate Credit Assessment, McGraw-Hill.

Beaver, W H, (1966), Financial Ratios as Predictors of Failure, Journal of Accounting Research, Vol 5, pp 71-111.

Breiman, L, Friedman, J H, Olshen, R A and Stone, C J, (1993), Classification and Regression Trees, Chapman \& Hall.

Clemens \& Dyer, (1979), Balance Sheets and the Lending Banker, Europa Publications.

Crook, J N, Hamilton, R and Thomas, L C, (1992), A Comparison of Discriminators Under Alternative Definitions of Credit Default, in Credit Scoring and Credit Control, (Eds) Thomas, L C, Crook, J N \& Edelman, D B, Oxford University Press.

Draper, N R and Smith, H, (1981), Applied Regression Analysis, 2nd Edition, John Wiley \& Sons, New York.

Eisenbeis, R A, (1977), Pitfalls in the Application of Discriminative Analysis in Business Finance and Economics, Journal of Finance, Vol 32, No 30, June, pp 1142-1153.

Gilbert, L R, Menon, K and Schwartz, K B, (1990), Predicting Bankruptcy for Firms in Financial Distress, Journal of Business Finance \& Accounting, Vol 17, No 1, pp 161-171. 
Hair, J F, Anderson, R E and Tatham, R L, (1987), Multivariate Data Analysis, Collier Macmillan.

Hamilton, R and Khan, M, (1997), Revolving Credit Card Holders: Who Are They and How Can They Be Identified, Loughborough University Banking Centre Research Paper Series No 109/97.

Klecka, W R, (1980), Discriminant Analysis, Sage University Paper No 19, (Series: Quantitative Applications in The Social Sciences).

Lewis, E M, (1994), An Introduction to Credit Scoring, Athena Press.

Morrison, D G Y, (1969), An Interpretation of Discriminant Analysis, Journal of Marketing Research, Vol VI, May, pp 156-163.

Platt, H D \& Platt, M B, (1990), Development of A Class of Stable Predictive Variables: The Case of Bankruptcy Prediction, Journal of Business Finance and Accounting, Vol 17, No 1, pp 31-51.

Press, S J \& Wilson, S, (1978), Choosing Between Logistic Regression and Discriminant Analysis, Journal of The American Statistical Association, Vol 73, pp 699-705.

Taffler, R J \& Tisshaw, H J, (1977), Going, Going, Gone: Four Factors Which Predict, Accountancy, Vol 88, No 1003, March, pp 50-54. 


\section{NOTES}

1. The classification of cases can also be based on other rules such as Bayes Rule, for example.

2. See Morrison (1969) for a fuller discussion on classification procedures.

3. A situation where two or more independent variables are highly correlated which would make the relative importance of any single variable unreliable.

4. Given that one objective of this research was to correctly classify members of both groups, the Cprop is a more appropriate measure of chance rather than the maximum chance criterion (Cmax) which would simply advise that all cases be assigned to the larger of the two groups.

5. An administrative receivership is only appointable under a mortgage debenture incorporating a floating charge (Sec 2, Insolvency Act, 1986). 
TABLE 1

SAMPLE COMPANIES BY INDUSTRIAL SECTOR

\begin{tabular}{|c|c|c|c|}
\hline Sector & Frequency & Rescued & Failed \\
\hline Agriculture & 1 & 1 & - \\
\hline Mining & - & - & - \\
\hline Manufacturing & 26 & 19 & 7 \\
\hline Wholesale Distribution & 8 & 5 & 3 \\
\hline Retail & 7 & 6 & 1 \\
\hline Construction & 15 & 5 & 10 \\
\hline Transport & 4 & 2 & - \\
\hline Finance & 10 & 8 & 2 \\
\hline Other Services & 1 & 1 & - \\
\hline \multirow[t]{2}{*}{ Hotel and Catering } & 2 & 2 & - \\
\hline & 74 & 49 & 25 \\
\hline
\end{tabular}

Note:

1. Sales turnover: $>£ 10$ million

13 companies

£5-10 million

26 companies

$£ 1-5$ million

42 companies

$<£ 1$ million

22 companies 
TABLE 2

RATIOS CONSIDERED IN THE ANALYSIS

Financial Ratios Considered

Ratios Used in the Analysis

\section{Operating Ratios}

PBIT/Turnover ${ }^{1}$ (PM)

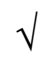

Trading Profit/Turnover

Trading Profit/Capital Employed

Overall Trends in Turnover (TT)

Turnover/Capital Employed

Stock/Turnover (ST)

Trade Debtors/Turnover (DT)

Debtors/Creditors

Trade Debtors/Trade Creditors

Trade Creditors/Cost of Purchases

Trade Creditors/Turnover

Working Capital/Turnover

\section{Financial Ratios}

Turnover/Net Fixed Assets

Gearing Ratio ${ }^{2}$ (GR)

Equity/Capital Employed

PBIT/Interest

Loan Capital/Capital Employed

PBIT/Capital Employed

Current Ratio ${ }^{3}$ (CR)

Acid Test Ratio ${ }^{4}$

Note:

1. Gross profit margin = profit before interest and taxation/sales turnover.

2. Gearing ratio $=$ debt/equity .

3. $\quad$ Current ratio = current assets/current liabilities.

4. $\quad$ Acid test $=$ current assets minus stock and WIP/current liabilities. 
TABLE 3

EXPERIMENTAL RESULTS FOR DATASET RE74 (UNEQUAL GROUPS)

\begin{tabular}{lcccc}
\hline \multicolumn{1}{c}{ Method } & $\begin{array}{c}\text { Apparent } \\
\text { Rate }\end{array}$ & \multicolumn{2}{c}{ Estimated Rate } & $\begin{array}{c}\text { Explanatory Variables } \\
\text { (Ranked in Order } \\
\text { of Importance) }\end{array}$ \\
\hline LDA (Enter) & 79.3 & 73.0 & 72.7 & DT, GR, CR, ST, PM, TT \\
LDA (Stepwise) & 74.3 & 74.3 & 75.3 & GR, DT \\
LR (Enter) & 81.1 & 75.7 & 72.7 & DT, GR, CR, ST, PM, TT \\
LR (Fwd-Stepwise) & 74.3 & 74.3 & 70.0 & GR, DT \\
\hline
\end{tabular}


TABLE 4

EXPERIMENTAL RESULTS FOR DATASET RE50 (EQUAL GROUPS)

\begin{tabular}{lcccc}
\hline \multicolumn{1}{c}{ Method } & $\begin{array}{c}\text { Apparent } \\
\text { Rate }\end{array}$ & \multicolumn{2}{c}{ Estimated Rate } & $\begin{array}{c}\text { Explanatory Variables } \\
\text { (Ranked in Order } \\
\text { of Importance) }\end{array}$ \\
\hline LDA (Enter) & 84.0 & 78.0 & 74.0 & DT, GR, CR, ST, PM, TT \\
LDA (Stepwise) & 80.0 & 76.0 & 80.0 & GR, DT, CR \\
LR (Enter) & 84.0 & 74.0 & 76.0 & DT, GR, CR, ST, PM, TT \\
LR (Fwd-Stepwise) & 80.0 & 76.0 & 80.0 & GR, DT, CR \\
\hline
\end{tabular}


TABLE 5

ANALYSIS OF THE 42 CASES WITH DT LESS THAN 64 DAYS

\begin{tabular}{ccccc}
\hline $\begin{array}{c}\text { DT Debtor } \\
\text { Turnover } \\
\text { (in days) }\end{array}$ & $\begin{array}{c}\text { TT Turnover } \\
\text { Trend (\% } \\
\text { annual change) }\end{array}$ & $\begin{array}{c}\text { Number of } \\
\text { Rescued Cases }\end{array}$ & $\begin{array}{c}\text { Number of } \\
\text { Failed Cases }\end{array}$ & Total \\
\hline$<64$ & $\mathrm{TT}<0$ & $14(33)$ & $12(29)$ & $26(62)$ \\
$<64$ & $0 \leq \mathrm{TT} \leq 15$ & $7(17)$ & $2(5)$ & $9(21)$ \\
$<64$ & $\mathrm{TT}>15$ & $1(2)$ & $6(14)$ & $7(17)$ \\
\hline
\end{tabular}

Note:

1. Brackets denote percentages. 
TABLE 6

SURVIVAL PATTERN WITH RESPECT TO GEARING RATIO

\begin{tabular}{cccc}
\hline Gearing Ratio & $\begin{array}{c}\text { No of } \\
\text { Rescued Cases }\end{array}$ & $\begin{array}{c}\text { No of } \\
\text { Failed Cases }\end{array}$ & Total \\
\hline $0.00-2.0$ & $10(14)$ & $2(2)$ & $12(16)$ \\
$2.0-10.0$ & $6(8)$ & $11(15)$ & $17(23)$ \\
$10.0-70.0$ & $15(20)$ & $8(11)$ & $23(31)$ \\
$>70.0$ & $18(24)$ & $4(5)$ & $22(30)$ \\
\hline
\end{tabular}

Note:

1. $\mathrm{N}=74$

2. Brackets denote percentages. 
TABLE 7

SURVIVAL PATTERN WITH RESPECT TO CURRENT RATIO

\begin{tabular}{cccc}
\hline Current Ratio & No of Rescued Cases & No of Failed Cases & Total \\
\hline Lowest -0.85 & $17(23)$ & $6(8)$ & $23(31)$ \\
$0.85-1.10$ & $13(18)$ & $12(16)$ & $25(34)$ \\
$>1.10$ & $19(26)$ & $7(9)$ & $26(35)$ \\
\hline
\end{tabular}

Note:

1. $\mathrm{N}=74$

3. Brackets denote percentages. 